\title{
IAMJ
}

INTERNATIONAL

AYURVEDIC

MEDICAL JOURNAL

ISSN: 23205091

Impact Factor: 5.344

Research Article

\section{AN OBSERVATIONAL STUDY TO ASSESS THE STATUS OF AGNI IN MIGRAINE PATIENTS}

\author{
Reshma M. A ${ }^{1}$, Anandalakshmy K. $\mathbf{N}^{2}$ \\ ${ }^{1}$ MD Scholar, Dept. Of Kriyasareera, Govt. AVC, Pariyaram, Kannur- 670503, Kerala, India \\ ${ }^{2}$ Professor\& HOD, Dept of Kriyasareera, Govt AVC, Trivandrum- 695035, Kerala, India
}

Email: reshmaantony88@gmail.com

https://doi.org/10.46607/iamj0807012020

(Published online: July 2020)

Open Access

(C) International Ayurvedic Medical Journal, India 2020

Article Received: 05/06/2020 - Peer Reviewed: 21/06/2020 - Accepted for Publication: 01/07/2020

Check for updates

\begin{abstract}
The function of digestion and metabolism, which is unavoidable for the maintenance of life, is performed by the Agni. When Agni functions properly, the individual remains healthy and becomes diseased when the same is disturbed. Migraine is a common disabling primary headache disorder with high personal and social costs, but its pathophysiology is not yet fully understood. As all the diseases are caused by the hypo-functioning of agni, it is essential to understand the status of agni in migraine patients. 75 Patients diagnosed with migraine were selected from the OPD and IPD of Government Ayurveda College Hospital Kannur, before intervention. Then their status of agni was assessed by using a validated agni assessment tool. It was developed by considering the specific features assigned to four functional states of agni. Then their disability was assessed by using MIDAS score. Statistical assessment was done by using descriptive statistics and spearman correlation coefficient. Status of agni in most of the migraine patients was not normal.
\end{abstract}

Keywords: Agni, Migraine disability, Samagni, Teekshnagni, Mandhagni, Vishamagni 


\section{INTRODUCTION}

Migraine is one of the most painful benign disorders known to medicine. The intensity of migraine attacks varies markedly among individuals. In a given person, particular symptoms may occur in one attack but not in another. It is a chronic condition characterised by recurrent attacks of throbbing head pain of 4 to 72 hours that may be accompanied by nausea, vomiting, and sensitivity to light and noise. Epidemiological studies have documented its high prevalence and high socio- economic and personal impacts ${ }^{1}$. Once migraine is diagnosed, the next important aspect is to assess the severity and degree of disability ${ }^{2}$. It is a common, debilitating disorder that imposes a large personal burden on sufferers and high economic costs on society. Migraine Disability Assessment Test [MIDAS] is one of the tools which are employed in assessing migraineurs disability.

In Ayurveda agni is a factor which controls and regulates homeostasis of the body ${ }^{3}$. All diseases are developed due to the hypo- functioning of $a g n i^{4}$. In clinical practise it was observed that, when the agni status was corrected in migraine patients, the disease as such get resolved. Ayurveda considers agni as the cause of life, complexion, strength, health, enthusiasm, nourishment, lustre, oja, teja, and prana. Extinction of this jadaragni leads to death. Its proper conservation helps a person to live a long life, and its impairment gives rise to diseases. Hence it is considered as the base of life ${ }^{5}$. Four statuses of agni were mentioned in classics. Samagni is characterised by strong and appealing appetite that is easily satisfied with normal food. $\mathrm{Vi}$ shamagni reflects variable functioning of agni. Tikshnagni digests the large quantity of food quickly, and at the end of digestion produces dryness of the throat, palate and lips, feeling of burning sensation and exhaustion by heat. Mandagni is that which digests the food even though proper, after long time producing heaviness of the abdomen, flatulence, constipation, gurgling noise in the intestines, dryness of the mouth, obstruction of flatus and such other features of indigestion.

\section{Materials and Methods}

75 migraine patients, irrespective of sex and age between 20 to 60 years were consecutively selected from the OPD and IPD of the Govt. Ayurveda College hospital, Kannur, Pariyaram before intervention. After the initial screening process, the patients were verbally informed about the basic details of the study. Consenting patients were asked to complete the written informed consent form in their regional language. After obtaining the written consent, preliminary data was collected. The agni status of the patient was assessed by using a validated agni assessment tool ${ }^{7}$. It was a self- assessment questionnaire for recording the strength of agni. The questionnaire contains total eleven questions with four options corresponding to four statuses of agni. For each question single score was assigned. After filling the eleven questions, total scores were calculated in respective columns. The status of agni was determined on the basis of maximum score obtained under the different categories of agni. Then their disability was assessed by using MIDAS test $^{8}$. MIDAS is a short self- administered and 7-item questionnaire to quantify headache- related disability in a span of three months. Among these seven questions only the first five questions were scored. This questionnaire measures the influence of headaches on three domains of activity (work, household work, and non- work activities) over the preceding three months. After that total score was obtained by totalling the total number of days, the patient was then assigned to one of the four levels of disability.

\section{Results}

\section{Distribution of status of agni}

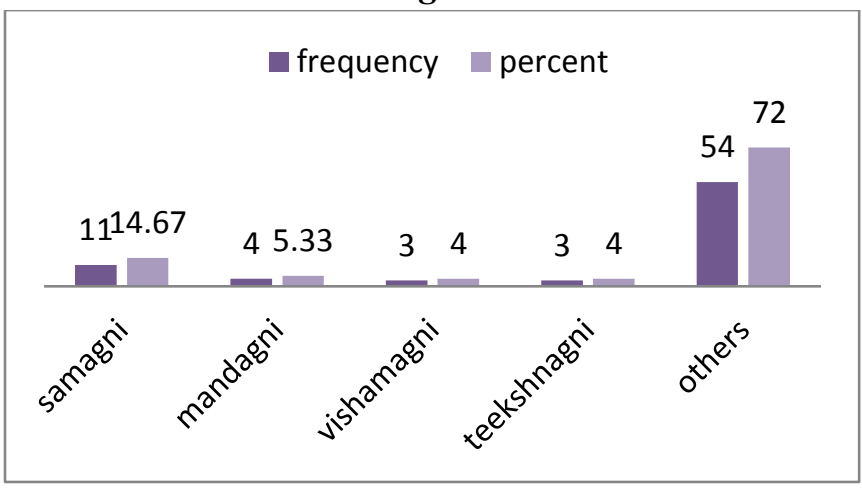


When a score of eight or above eight got for any single status of agni, it was considered as pravara. Out of 75 patients, only $14.67 \%$ of patients had pravara samagni, $5.33 \%$ had pravara mandagni, $4 \%$ had pravara vishamagni and $4 \%$ had pravara tikshnagni, and remaining $72 \%$ of participants had agni status in combination of two or three.

Table 1:

\begin{tabular}{|l|l|l|}
\hline Spearman correlation between & Correlation coefficient & Significance (1- tailed) \\
\hline Mandhagni \& MIDAS score & 0.140 & 0.115 \\
\hline Vishamagni \& MIDAS score & 0.125 & 0.142 \\
\hline Samagni \& MIDAS score & -0.242 & 0.018 \\
\hline Tikshnagni \& MIDAS score & -0.203 & 0.040 \\
\hline
\end{tabular}

Each score of agni was separately analysed for correlation with migraine disability score using spearman correlation coefficient. MIDAS score had significant negative correlation with samagni \& tikshnagni score and in- significant positive correlation with mandhag$n i$ \& vishamagni score. This shows that when the score of samagni or tikshnagni increases migraine disability decreases.

\section{DISCUSSION}

Only 14.67 percentage of 75 patients had good agni status ie samagni and remaining all had a vitiated agni status. None of the patients had got a score eleven for any of the four agni status. In majority of the patients, score obtained for single agni status was below eight, so it can't be taken as having any single status. Their agni status was divided into combination of two or three of the four agni status. In classics it was mentioned that a combination of samagni and teekshnag$n i^{9} \&$ samagni and mandhagni ${ }^{10}$ can be called as $v i$ shamagni. As $72 \%$ of the patients were having a varying agni status, it can be considered as vishamagni. In the case of mandagni, the digestive power of the individual was weak, and there will not be proper and complete digestion of food. In the case of vishamagni as it was a varying digestive power, sometimes the food will be digested, absorbed and assimilated in proper time but sometimes not. So, in mandagni and vishamagni there will be formation of ama in koshta. This was the case when only jatharagni was considered. When jatharagni becomes abnormal, other agnis dependent on it also becomes abnormal. So, there will be accumulation of ama in the dhatu level also. So, when the score of vishamagni and mandhagni increases, there will be increased accumulation of ama which leads to the precipitation of migraine disease and further increases the migraine disability. As the status of agni was a functional aspect of a human being, large sample size was needed to get statistical significance. That might be the reason for the statistical insignificance. But in the case of samagni, the digestive power is normal and there will be proper digestion and no ama formation. In the case of teekshnagni as the digestive power is strong, there will be fast digestion and no ama formation. So as the score of samagni or teekshnagni increases there will not be any disease or disability. But in the case of teekshnagni, after a normal level it can develop the disease bhasmaka.

\section{CONCLUSION}

The agni status of most of the migraine patients participated in the study was vishama. MIDAS score had significant negative correlation with samagni \& tikshnagni score and in- significant positive correlation with mandhagni \& vishamagni score.

\section{REFERENCES}

1. Headache Classification Committee of the International Headache Society (HIS). The international classification of headache disorders, $3^{\text {rd }}$ edition (beta version). Cephalalgia. 2013; 33(9): 644- 655.

2. Chakma J. How to assess the severity of your migraine headache? [Internet]. 2011 [cited 2017Apr15]. Available from: http://www.ichd-3.org/1-migaine/ 
3. Acharya Agnivesa, Charaka Samhita (vol 3). Reprint edition. Translated by R K Sharma, Bhagwan Dash. Varanasi: Chaukambha Sanskrit series office; 2015. Charaka samhita Sutrasthanam 5.

4. Acharya Vagbhata, Ashtanga Hridayam (vol 2). Reprint edition. Translated by K. R. Srikantha Murthy, Varanasi: Chaukambha Krishnadas Academy; 2014. Ashtanga Hrudayam Nidanam 12.

5. Acharya Agnivesa, Charaka Samhita (vol 4). Reprint edition. Translated by R K Sharma, Bhagwan Dash. Varanasi: Chaukambha Sanskrit series office; 2015. Charaka samhita Chikitsasthanam 15.

6. Acharya Vagbhata, Ashtanga Sangraha (vol 1). Reprint edition. Translated by K. R. Srikantha Murthy, Varanasi: Chaukambha Orientalia; 2012. Ashtanga Sangraham Sarirasthanam 6.

7. Kishor Patwardhan et al. Development, validation and verification of a self-assessment tool to estimate $\mathrm{Ag}$ nibala. Evidence based Complementary and Alternative Medicine, July 2016.

8. Dan L. Longo, Dennis L. Kasper, J. Larry Jameson. Et al. Harrison's principles of internal medicine. $18^{\text {th }}$ edition. Part 2.P 117.

9. Acharya Susrutha, Susrutha Samhita (vol 1). Reprint edition. translated by K. R. Srikantha Murthy, Varanasi: Chaukhambha Orientalia;2014. Susrutha Samhita Sutrasthana 35.

10. Acharya Vagbhata, Ashtanga Hridayam (vol 2). Reprint edition. Translated by K. R. Srikantha Murthy, Varanasi: Chaukambha Krishnadas Academy; 2014. Ashtanga Hrudayam Sarirasthanam 3.

\section{Source of Support: Nil \\ Conflict of Interest: None Declared}

How to cite this URL: Reshma M. A, Anandalakshmy K. N: An Observational Study To Assess The Status Of Agni In Migraine Patients. International Ayurvedic Medical Journal \{online\} 2020 \{cited July, 2020\} Available from: http://www.iamj.in/posts/images/upload/3827_3830.pdf 